\title{
Construction of Self-compiled Teaching Materials for Agricultural Professional Master Degree Courses
}

\author{
Yihong Hu*, Wenshuai Zeng, Chenzhong Jin, Xuejiao Zhang, Yong Chen \\ Key Laboratory of Harmless Application of Pesticide in Hunan Higher Education \\ Hunan University of Humanities, Science and Technology \\ Loudi 417000, Hunan, China \\ huyhongwangyi@163.com
}

\begin{abstract}
The culturing goal of agricultural professional master degree is to educate qualified talents with innovative and vocational abilities for the local economical construction and the selection of teaching materials for students is a key ring in education. At present, some of the teaching materials adopted in this degree unit lack specialty features or local features. At the same time, in the local universities, vocational features of teaching materials are often overemphasized, and the forms of teaching materials are homogenized. In recent years, Hunan University of Humanities, Science and Technology has set up a new training mode which is "three-double, four-module, and seven-period" training mode, and compiled a series of teaching materials to fit with this new mode. In this paper, we introduced the construction of self-compiled teaching materials used for this new training mode. It will be valuable experience for the other scientific and educational institutions.
\end{abstract}

Keywords-agricultural professional master degree; selfcompiled teaching material; new training mode

\section{INTRODUCTION}

Since the agricultural professional master degree system was first established in 1999, over 70 universities and scientific institutes have acquired the right to enroll postgraduate students of agricultural professional master degree in our country to date [1]. In 2011, Hunan University of Humanities, Science and Technology became the first newly-upgraded local university which was granted for the pilot qualification for culturing postgraduate students of agricultural professional master. At the beginning, four specialties were set up in this degree unit in Hunan University of Humanities, Science and Technology including plant protection, crop, regional and rural development, and agricultural information. The degree unit was evaluated by the National Agricultural Professional Master Degree Teaching and Steering Committee in 2017, and then the existed four specialties were adjusted to resource utilization and plant protection, agronomy and seed industry, rural development, and agricultural engineering and information technology, respectively, and now over 130 postgraduate students have graduated and acquired the master's degrees in recent years.

The culturing goal of agricultural professional master

This research was financially supported by Innovation Base for Postgraduates Cultivation of Hunan Province (2261602) and Research Project of Teaching Reform of Degree and Graduate Education in Hunan (JG2016B106). degree is to cultivate high applied and compound talents for the local economical development [2]. Thus, the training mode should dock the local agricultural enterprises in order to provide high technical and management personnel for agricultural industries and enterprises. Besides the vocational abilities, the innovative abilities are also needed for the postgraduate students [3]. Consequently, during culturing the postgraduate students of agricultural professional master degree, we should emphasize the unity of professionalism and scholarship. Based on this idea, Hunan University of Humanities, Science and Technology created a new talents training mode, i.e. three-double, four-module, and seven-period training mode, where three-double means culturing postgraduate students by the university and enterprises, by on campus tutors and off campus tutors, and by alternating of theory and practice; four-module means that the curriculum system includes the common required courses, the main backbone courses, the specialized skill courses, and the specialized development courses, and seven-period means that during the whole schooling length, the training terms are divided into seven continuous periods according to the agricultural production and the students are trained alternatively through theory and practice training [4]. In this way, five grades of students have graduated from our university successfully, and all of them were accepted and their abilities were highly appreciated by the society.

The selection of teaching materials is a significant link in the cultivation of postgraduate students of agricultural professional master degree to realize the culturing goal of the vocational abilities and the innovative abilities. Early investigations revealed that most of the postgraduate students of agricultural professional master degree were not satisfied with the existed course contents because these courses lacked novelty and there was a great gap between the training contents and the actual development of the rural areas [5-6]. Based on these conditions, in Hunan University of Humanities, Science and Technology, we set up a new training mode, that is, threedouble, four-module, and seven-period training mode, to make closer the social needs for postgraduate students and their abilities. Correspondingly, we made reforms on course modules and teaching materials to fit with the new training mode. In this paper, we introduced the experiences of construction of the self-compiled materials for the agricultural 
professional degree courses to meet with the culturing goal, and hope to provide some helpful references for the other scientific and educational institutions.

\section{CURRENT SITUATIONS OF TEACHING MATERIALS} APPLIED FOR AGRICULTURAL PROFESSIONAL COURSES IN OUR COUNTRY

\section{A. Teaching Materials Lack Their Specialty Features}

Some of the units of agricultural professional master degree still educate postgraduate students according to the academic type. Especially in some of the comprehensive universities, the students responded that the evaluation systems mainly rely on the scientific value of the academic dissertations [7]. Then most of the courses and the adopted teaching materials are according to the academic type. The main reason of this phenomenon is owing to the fact that the culturing goal of agricultural professional master degree has not been wellunderstood in these scientific and educational institutions. Especially in some comprehensive universities, people still want to educate all-round talents to adapt diversified occupations [6]. Therefore, these practices resulted in the similar teaching materials used in the education of agricultural professional degree as compared to those in the education of the academic type or undergraduate type, and finally the teaching materials used for the professional degree lacked their specialty characteristics.

\section{B. Teaching materials lack local features}

Some of the local universities have been granted for the qualification for the cultivation of professional postgraduate students in recent years. These institutions often simulate the comprehensive universities to educate postgraduate students because they lack necessary practices and have not enough experiences at the beginning. They preferred to simulate or copy the talent training programs from the comprehensive universities, and in some cases, they even adopted the same teaching materials simply. Consequently, the teaching materials they adopted lacked the local features, and it was difficult to educate qualified postgraduate students for the local economical construction under these training modes.

\section{Vocational features are overemphasized in local universities}

In the local universities, the vocation-oriented education on postgraduate students is the characteristics. It is true that this training mode will be helpful to promote the vocational abilities of the postgraduate students of agricultural professional master. But we should like to educate high composite talents with the vocational abilities and the innovative abilities to adapt the local economical construction, and our goal is not just to cultivate technicians. The students should not only know the agricultural technologies but also understand the mechanisms, and they can use the principles in their further work. However, at the beginning of postgraduate education, we also overemphasized the vocational features and laid focus on promoting the practical abilities of the students. In the agronomy and seed industry specialty of our universities, some text books for technical colleges have ever been used before. For example, we used to adopt a text book for technical colleges as the teaching material of the course soil fertilizer science, and the students fed back that the teaching effect was not satisfactory and the knowledge they acquired was not systematically.

\section{Teaching materials are homogenized}

There are very few types of textbooks for the training of postgraduate students of agricultural professional master. In most universities, only two types of textbooks are adopted in teaching: theoretical textbooks and experimental textbooks. As for the resource utilization and plant protection specialty in Hunan University of Humanities, Science and Technology, the professional courses for postgraduate students were set as shown in Table I, and the practice teaching materials and the case teaching materials are needed for the training, but it is very difficult for us to make use of the existing published teaching materials.

TABLE I. PROFESSIONAL COURSES FOR RESOURCE UTILIZATION AND PLANT PROTECTION SPECIALTY IN HUNAN UNIVERSITY OF HuMANITIES, SCIENCE AND TECHNOLOGY

\begin{tabular}{|l|l|l|l|}
\hline No. & Course name & Course type & Teaching method \\
\hline 1 & Experiment design and biostatistics & Main backbone course & Traditional inculcating teaching and experiment \\
\hline 2 & Agricultural resources and pests survey and evaluation & Main backbone course & Traditional inculcating teaching and practice \\
\hline 3 & Comprehensive control on plant pests & Main backbone course & Traditional inculcating teaching and practice \\
\hline 4 & Efficient use and management of agricultural products & Main backbone course & Case teaching \\
\hline 5 & Safety production technology of agricultural products and applications & Main backbone course & Traditional inculcating teaching and practice \\
\hline 6 & Development of resource utilization and plant protection technology & Main backbone course & Discussion \\
\hline 7 & Agricultural environmental protection and ecological engineering & Selective course & Case teaching \\
\hline 8 & Weeds control technology & Selective course & Traditional inculcating teaching and practice \\
\hline 9 & Plant protection technology & Selective course & Traditional inculcating teaching and practice \\
\hline 10 & Agricultural laws and regulations & Selective course & Traditional inculcating teaching and practice \\
\hline 11 & Scientific paper writing & Selective course & Traditional inculcating teaching and practice \\
\hline
\end{tabular}

III. CONSTRUCTION OF SELF-COMPILED TEACHING MATERIALS

\section{A. Compiling teaching materials with distinctive locality}

Hunan University of Humanities, Science and Technology locate in the central part of Hunan Province, and the main crop in this area is rice. In recent years, facility agriculture and horticulture also have been developed rapidly. The ordinary teaching materials on agriculture are not fit for this district. Especially, we found that it is very difficult to select suitable practical teaching materials for the resource utilization and plant protection specialty and the agronomy and seed industry specialty. In response to this situation, we compiled and 
published several text books including "Facility agriculture technology", "Common garden plants", "Principle and practice of professional control and large-scale prevention of rice pests and diseases", and "Identification and monitoring of major pests in crops" etc. All of these teaching materials have distinctive locality, and have been used in the practical trainings in the main backbone courses and the selective courses.

At the same time, the case teaching is a tendency in the cultivation of students of professional degree because it is a more efficient way to train the practical abilities and innovative abilities. Obviously, it is more vivid and interesting than the traditional methods such as inculcation or discussion. In 2013, Hunan University of Humanities, Science and Technology started the construction of teaching cases for postgraduate student project and compiled a casebook including a series of cases such as "Application of biotechnology in the development of kudzu products in XL industry group" and "The rising of Wanjiafeng Crop Agricultural Cooperative on disease and pest control". Included in each of the cases are two parts: case body and case instruction for use. In the case body, there are abstract, introduction, case contents, and summary, and the number of words in each case was restricted to 5000 words in order to use it within two periods of class. In the case instruction for use, we illustrated the courses, objects, teaching objective, using method in class, and case analysis. All of these cases were from the cooperative enterprises and these real examples are convincing, with distinctive locality, and interesting to students. In this way, we promoted the case teaching rate in the cultivation gradually.

\section{B. Compiling theoretical teaching materials}

In our "three-double, four-module, and seven-period" training mode, the students are trained in the sequence of theory-practice-theory alternatively. In order to teach the theory knowledge systematically, we compiled and published several teaching materials to promote the teaching efficiency such as "Concise tutorial of life science knowledge" and "Agricultural biotechnology tutorial". In these textbooks, the biology and biotechnology knowledge relative to agriculture was introduced in a concise and systematical way, and relative experiments such as the specimen productions of plants and insects and applications of enzyme engineering in plant protection were included. The postgraduate students can not only be trained with fundamental knowledge but also promote their practical technique.

\section{Compiling treatises as auxiliary teaching materials}

In order to make the training contents closer to the local agricultural condition, the teachers in our university have compiled the recent years' researches results into treatises, and used them as auxiliary teaching materials. For the time being, two books have been published, which are "In vitro porcine embryo production technology" and "Applications and research of rice seed coating agents", and another two books are in process of compiling. These books have distinctive local features and are suitable to train the practical and innovative abilities for postgraduate students.

\section{SUMMARY}

The most degree units of agricultural professional master have not suitable teaching materials which have distinctive local features to cultivate postgraduate students with innovative abilities and vocational abilities. From 2011, Hunan University of Humanities, Science and Technology created a new mode to cultivate talents, which is "three-double, four-module, and seven-period" training mode, and compiled a series of teaching materials (Table II) and gained an ideal teaching effect. These practices will be valuable experience for other scientific and educational institutions.

TABLE II. PART OF SELF-COMPILED MATERIALS USED IN HUNAN UNIVERSITY OF HUMANITIES, SCIENCE AND TECHNOLOGY FOR CULTIVATION OF POST GRADUATE STUDENTS OF AGRICULTURAL PROFESSIONAL MASTER

\begin{tabular}{|c|c|c|c|c|}
\hline No. & Self-compiled material & Type & Statue & Main author \\
\hline 1 & Facility agriculture technology & $\begin{array}{l}\text { Theory and practice } \\
\text { training }\end{array}$ & Published & Yihong $\mathrm{Hu}$ \\
\hline 2 & Common garden plants & Practice training & Published & Chenzhong Jin \\
\hline 3 & $\begin{array}{l}\text { Principle and practice of professional control and large-scale prevention of rice pests } \\
\text { and diseases }\end{array}$ & $\begin{array}{l}\text { Theory and practice } \\
\text { training }\end{array}$ & Published & Chenzhong Jin \\
\hline 4 & Identification and monitoring of major pests in crops & Practice training & Published & Jingbo Li \\
\hline 5 & Food science and engineering & Practice training & $\begin{array}{l}\text { Under } \\
\text { publishment }\end{array}$ & Zhiyin Chen \\
\hline 6 & Research on garden plants of Dongtinghu areas & Practice training & Published & $\begin{array}{l}\text { Guohong } \\
\text { Xiang }\end{array}$ \\
\hline 7 & Crop production technology & Practice training & Published & Guiyuan Meng \\
\hline 8 & Process in biotechnology & Practice training & Published & Zhi Zeng \\
\hline 9 & $\begin{array}{l}\text { Application of biotechnology in the development of kudzu products in XL industry } \\
\text { group }\end{array}$ & Case teaching & Internal document & Yihong $\mathrm{Hu}$ \\
\hline 10 & The rising of Wanjiafeng Crop Agricultural Cooperative on disease and pest control & Case teaching & Internal document & Chenzhong Jin \\
\hline 11 & In vitro porcine embryo production technology & Treatise & Published & Junhe $\mathrm{Hu}$ \\
\hline 12 & Applications and research of rice seed coating agents & Treatise & Published & Yihong $\mathrm{Hu}$ \\
\hline
\end{tabular}




\section{REFERENCES}

[1] Q. Ren, J. Xuan, S. Wang, J. Hua, Z. Hu, A. Wen, and L. Wang, "Developing status of agricultural professional master in culture field and its reform in improving education quality," Anhui Agricultural Science Bulletin, vol. 23, pp. 143-146, 2017.

[2] W. Wang, J. Liu, and Y. Yang, "Research on training mode of agricultural professional master degree in south Xinjiang area: an example from Tarim University,” Journal of Higher Education, vol. 12, pp. 46, 49, 2016. (In Chinese)

[3] L. Song, "Practice and thought on postgraduates education with full-time agricultural professional degree: a case study of distant-water fisheries speciality,” Chinese Agricultural Science Bulletin, vol. 32, pp. 202-205, 2016.

[4] Y. Chen, F. Zhou, and J. Peng, "Exploration and practice of training mode "three-double, four-module, and seven-period" on cultivation of postgraduate students of full-time agricultural professional master degree,” Academic Degrees and Graduates Education, vol. 3, pp. 37-43, 2017. (In Chinese)

[5] Q. Li, and J. Wang, "Investigation and analysis of teaching and cultivation of full-time postgraduate students of agricultural professional master degree: an example of regional and rural development specialty of Jiangnan University,” Higher Agricultural Education, vol. 5, pp. 9295, 2016. (In Chinese)

[6] Q. Li, and J. Wang, "Problems and thinking of courses construction for full-time postgraduate students of agricultural professional master degree," China Agricultural Education, vol. 4, pp. 51-56, 2016. (In Chinese)

[7] F. Zhang, G. Ye, and X. Yuan, "Evaluating the full-time master of agricultural extension from the perspective of graduated students - case study on the program in Zhejiang University,” Bulletin of Science and Technology, vol. 31, pp. 247-251, 2015. 